\title{
Song Keplek: Okupasi Intensif Manusia Pada Periode Pasca- Plestosen Di Gunung Sewu
}

\section{Retno Handini; Harry Widianto}

Keywords: holocene, cave, settlement, gunung sewu, mongoloid, australomelanesian

\section{How to Cite:}

Handini, R., \& Widianto, H. (1998). Song Keplek: Okupasi Intensif Manusia Pada Periode Pasca-Plestosen Di Gunung Sewu. Berkala Arkeologi, 18(2), 72-91. https://doi.org/10.30883/jba.v18i2.785

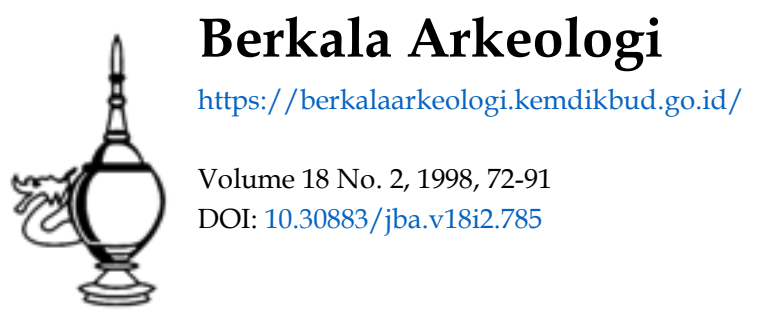

\section{(c) (1) 8 (2)}

This work is licensed under a Creative Commons Attribution-NonCommercial-ShareAlike 4.0 International License. 


\title{
SONG KEPLEK : OKUPASI INTENSIF MANUSIA PADA PERIODE PASCA-PLESTOSEN DI GUNUNG SEWU
}

\author{
Retno Handini" \\ Harry Widianto"
}

Song Keplek merupakan sebuah gua (cave) yang berada di jajaran Pegunungan Selatan Jawa, yang secara tradisional dikenal dengan sebutan Gunung Sewu. Daerah yang memanjang dari barat (Wonosari) ke timur (Pacitan) ini memiliki bentang morfologi tersendiri yang khas, yang dicirikan oleh perbukitan karst berbentuk sinoid. Di salah satu lereng perbukitan inilah --yang secara administrasi termasuk dalam wilayah Desa Pagersari, Kecamatan Punung, Kabupaten Pacitan-- Song Keplek terletak, sekitar 300 meter di sebelah barat daya jalan raya Wonogiri - Pacitan.

Song Keplek menghadap ke tenggara, pada ketinggian 333 meter di atas permukaan laut (Handini, 1996). Dengan berbagai runtuhan blok-blok gamping yang saat ini memenuhi ruangan utama gua, menyebabkan tertutupnya lorong-lorong gua yang terdapat di dalamnya, sehingga ruangan yang tersisa saat ini lebih mengesankan sebagai sebuah ceruk payung (rock-shelter). Dari sudut keruangan, gua ini tergolong luas dengan lantai yang relatif datar dan kering. Ukuran minimal ruang gua adalah 20 meter (timur laut - barat daya) x 7 meter (barat laut - tenggara), dengan tinggi langitlangit mencapai 7 meter. Aspek keruangan yang demikian tersebut membuat sirkulasi udara dan penyinaran sangat baik. Di samping itu, keletakan gua yang berada di lereng bawah bukit juga membuat gua mudah dicapai. Di depan gua membentang lereng sempit yang diapit dua bukit karst dan menurun hingga Kali Pasang yang berjarak sckitar 200 meter di sebelah tenggaranya. Sungai ini memasuki terowongan di bawah bukit karst lainnya hingga tembus kembali di arah barat laut. Daerah-daerah di sekitar gua merupakan perbukitan karst yang mengapit lembah dataran sempit yang saat ini dimanfaatkan penduduk untuk lahan pertanian. Dalam situasi gua dan lingkungannya tersebut, eksistensi Song Keplek merupakan sebuah gua yang layak huni bagi komunitas hunian gua di masa prasejarah, sejak paling tidak 10.000 tahun lalu dalam batas Plesto-Holosen. Beberapa syarat utama bagi sebuah gua untuk dihuni dapat ditemukan pada Song Keplek, yaitu : ruangan yang cukup luas dengan lantai yang relatif datar, akses yang mudah, sirkulasi udara dan sinar yang baik, lantai yang kering dan tidak terlalu lembab, dan lingkungan yang dekat dengan sumber air. Hal ini terbukti pada saat gua ini ditemukan pada tahun 1992, melalui berbagai indikasi pemukiman gua prasejarah yang terutama untuk daerah ini dieirikan oleh serpihanserpihan batu rijang scbagai bagian dari industri litik, alat-alat tulang, cangkang

\footnotetext{
- Pusat Penelitian Arkeologi Nasional

* Balai Arkeologi Yogyakarta
} 
kerang, sisa fauna, sisa pembakaran, kreweng, dan berbagai unsur hunian gua lainnya (Simanjuntak dan Retno Handini, 1997).

\section{- Stratigrafi, Karakter Budaya, dan Sisa Fauna di Song Keplek}

Sejak ditemukan pada tahun 1992, hingga saat ini (1999) Song Keplek telah diekskavasi sebanyak 5 kali oleh Bidang Prasejarah Pusat Penelitian Arkeologi Nasional. Potensi arkeologis yang dimilikinya menuntut bentuk penelitian yang sistematis dan konseptual dalam jangka waktu lama. Sebanyak 10 buah kotak ekskavasi telah digali selama 7 tahun pertama ini, yang sebagian besar berukuran $2 \mathrm{x}$ 2 meter. Rata-rata kedalaman yang dicapai dalam ekskavasi sekitar $200 \mathrm{~cm}$ dari SDP, dengan kotak D7 sebagai kotak terdalam, mencapai kedalaman $550 \mathrm{~cm}$ dari SDP.

\section{- Stratigrafi endapan gua}

Sebanyak 5 perlapisan tanah secara umum tergambar pada dinding stratigrafi kotak ekskavasi, dengan berbagai kandungan temuan artefaktual maupun ekofaktual yang hampir seragam antara satu kotak dengan kotak lainnya, dalam derajad kuantitas yang berbeda. Stratigrafi umum Song Keplek dapat digambarkan sebagai berikut :

Lapisan 1, berupa lempung warna coklat tua, tidak kompak, teraduk. Lapisan ini mempunyai variasi ketebalan antara $10 \mathrm{~cm}$ sampai dengan $30 \mathrm{~cm}$, dengan kandungan temuan berupa serpih rijang, pecahan tembikar, sisa fauna, dan terkadang ditemukan pecahan genteng.

Lapisan 2, berupa lempung warna coklat, tidak kompak, mengandung sisipan gamping terbakar, akumulasi serpihan rijang, sisa fauna dan fragmen-fragmen kerang. Tebal lapisan berkisar antara $25 \mathrm{~cm}$ hingga $100 \mathrm{~cm}$, dengan --antara lain-- dari kotak D3, pada bagian bawah lapisan ke 2, telah ditemukan 2 buah fragmen tengkorak dewasa (individu pertama dan kedua) dan sebuah atap tengkorak anak-anak berusia antara 7-9 tahun telah ditemukan (individu ketiga) pada kotak B6, di sekitar abu pembakaran. Pertanggalan C-14 bagi lapisan ini menghasilkan angka 4.510 $\pm 90 \mathrm{BP}$ (Simanjuntak, 1998).

Lapisan 3, lempung coklat kemerahan, sering sekali dalam bentuk bongkah dan disisipi lensa-lensa abu pembakaran dengan tulang dan cangkang yang terbakar di sekitarnya, ketebalan lapisan antara $50 \mathrm{~cm}$ hingga $60 \mathrm{~cm}$. Bagian atas lapisan mengandung komponen industri litik yang sangat padat, tetapi semakin ke bawah sisa fauna menjadi lebih dominan. Temuan spektakuler rangka lainnya yang relatif utuh dengan penguburan terlipat (individu keempat) dihasilkan dari LU2 pada kedalaman 
$112 \mathrm{~cm}$, dengan pertanggalan C-14 adalah 5.900 180 BP (Simanjuntak, 1998). Dari beberapa kotak ekskavasi, telah berhasil diketahui pertanggalan lain untuk lapisan ini, yaitu : $6.466 \pm 142 \mathrm{BP}$ pada kedalaman $-115 \mathrm{~cm}$ di kotak F8, dan $7.580 \pm 210 \mathrm{BP}$ pada kedalaman -143 di kotak B6.

Lapisan 4 , lempung coklat keputihan hingga kemerahan, sering dalam bentuk bongkah, dengan bongkah batu gamping dan sisipan lensa gamping terbakar berwarna abu-abu, setebal antara $90 \mathrm{~cm}$ hingga $100 \mathrm{~cm}$. Kandungan temuan antara lain berupa rijang dan sisa fauna. Dua pertanggalan dihasilkan bagi lapisan ini di kotak B6, yaitu $8.230220 \mathrm{BP}$ pada kedalaman - $194 \mathrm{~cm}$, dan $8.870 \pm 210$ BP pada kedalaman - 218 $\mathrm{cm}$ dari permukaan.

Lapisan 5, lempung coklat kemerahan, tidak kompak, ketebalan antara $100 \mathrm{~cm}$ hingga lebih dari $300 \mathrm{~cm}$, mengandung serpihan rijang dan sisa fauna. Sisipan lapukan batugamping dan abu bekas pembakaran dijumpai pada kotak F8, sehingga menghasilkan bercak putih dan hitam. Pertanggalan C-14 untuk lapisan ini di kotak F8 menghasilkan angka $15.880 \pm 540 \mathrm{BP}$ pada kedalaman $-240 \mathrm{~cm}$ hingga $-300 \mathrm{~cm}$.

\section{- Karakter Industri Litik}

Dari masing-masing perlapisan Song Keplek di atas, teridentifikasi bahwa kegiatan industri litik berlangsung sangat intensif di gua ini. Kandungan temuan menunjukkan bahwa serpih-serpih rijang ditemukan mulai dari permukaan hingga kedalaman 5 meter, dalam konteks sisa fauna dari berbagai jenis binatang, baik mikro maupun makro fauna. Intensitas pembuatan alat batu ini dicirikan oleh sebaran serpih rijang yang padat secara vertikal maupun horisontal, keberadaan alat yang digunakan untuk pembuatan alat (fabricator), tersedianya batu inti dengan tingkat pengerjaan yang bervariasi, maupun terdapatnya alat-alat yang belum selesai dikerjakan.

Di antara peralatan yang dihasilkan, serpih-serpih tanpa retus, serpih-serpih dengan tanda pemakaian, dan serpih-serpih yang dikerjakan lebih lanjut, merupakan jenisjenis alat yang paling menonjol (Simanjuntak, 1997). Seluruhnya menampakkan aspek morfologis yang beragam. Bentuk-bentuk serpih dapat dikategorikan pada bentuk persegi, segitiga, sisi membulat, dan tidak beraturan. Keragaman morfologis ini dipengaruhi oleh tahapan pengerjaan dan sasaran yang ingin dicapai si pembuat. Serpih yang memiliki korteks di bidang dorsal cenderung sebagai produk pengerjaan awal batu inti. Terkadang serpih semacam ini dikerjakan melalui atau tanpa peretusan. Serpih-serpih besar dengan panjang melebihi $4 \mathrm{~cm}$ sangat jarang ditemukan. Ukuran paling dominan berkisar antara 2-3 cm, dengan lebar antara 1-2.5 cm. Serpih-serpih kecil dapat merupakan pecahan-pecahan non-intensional di kala pemangkasan, dan dapat pula berupa serpih pembentukan alat. 
Aspek teknologis menghadirkan ciri-ciri umum berupa dataran pukul yang disiapkan sebelum pelepasan, bulbus yang terjadi di bidang ventral sebagai akibat tekanan kala pemangkasan, pangkasan-pangkasan longitudinal di bagian dorsal sebagai pangkasan pendahuluan untuk memperoleh bentuk yang diinginkan atau bekas pemangkasan serpih lain, dan retus-retus pengerjaan untuk penyempurnaan bentuk tajaman. Variasi teknologi tampak pada dataran pukul (lebar, sempit, datar, berfaset), bidang dorsal dengan atau tanpa korteks, dan bentuk-bentuk retus. Keberadaan retus ini cukup bervariasi dilihat dari keletakannya (bersambung dan terpencar), kemiringan (mendatar atau lurus), ukuran (mikro atau makro), serta lokasi retus (sisi lateral, distal, atau proksimal).

Tipologi artefak litik yang dihasilkan cukup bervariasi (Gambar 1), yang secara kuantitas maupun kualitas menunjukkan perbedaan antara satu alat dengan alat lainnya. Tipe-tipe alat yang dihasilkan adalah (Simanjuntak dan Retno Handini, 1997)

Serut, dicirikan oleh keberadaan retus bersambung menutupi seluruh atau sebagian sisi alat. Jenis ini merupakan jenis yang dominan, dengan retus yang cenderung bersifat marginal, walaupun terkadang terdapat retus memanjang secara sporadis. Keletakan retus di berbagai bagian alat menghasilkan tipe serut samping dan serut ujung, sementara ukuran dan jumlah retus melahirkan tipe serut cekung dan serut gigir. Juga terdapat serut ujung meruncing atau berpunggung tinggi, serut membulat, ataupun serut berpunggung korteks.

Serpih tanpa retus, jumlahnya paling dominan di antara kelompok alat. Kelompok ini mempunyai ciri yang sama dengan serpih yang diretus untuk dijadikan alat dalam hal morfologi, teknologis, maupun metrik. Perbedaannya terletak pada ketiadaan retus pada sisinya, sehingga merupakan serpih yang dilepas dari batu intinya dan tidak dipakai.

Serpih dengan retus pemakaian, juga sangat dominan dan selalu ditemukan di setiap kotak ekskavasi. Ciri morfo-teknologisnya sama dengan serpih tanpa retus, yang berbeda dalam hal kehadiran perimping-perimping bekas pemakaian. Eksistensi alat ini merupakan bukti dari teknologi cepat (expeditive technology) dan umumnya ditujukan pada pemakaian okasional.

Bilah dengan retus, cukup merata ditemukan pada kotak-kotak ekskavasi. Alat ini mempunyai ciri-ciri teknologis yang sama dengan serpih, dengan perbedaan pokok pada morfologi yang memanjang dengan kedua sisi lateral yang relatif sejajar. Keteraturan sisinya agaknya membuat pengerjaan kedua kali tidak lagi dibutuhkan.

Bor, dicirikan oleh bagian runcing (umumnya di bagian distal) yang dibentuk secara sengaja, sering sekali melalui penyempurnaan peretusan lanjut pada salah satu sisi 
atau kedua sisi. Ada kalanya runcingan terletak pada salah satu sudut dengan arah menyilang terhadap sumbu alat. Sering pula runcingan dibuat dengan mengerjakan salah satu sisi lebih intensif dibandingkan sisi lainnya, sehingga melahirkan bentuk khas melengkung.

Lancipan, dibentuk melalui pemangkasan sekunder pada kedua sisi lateral hingga membentuk runcingan di bagian distal. Pada tipe ini, bagian yang runcing selalu di bagian distal dan diciptakan secara berstruktur dan teratur, mulai bagian pangkal hingga ujung alat. Bentuk lancipan umumnya mengarah pada segitiga dengan tinggi (panjang) lebih dominan dibandingkan bagian dasar (lebar).

Mata panah, umumnya masih belum selesai. Bentuk umum segitiga sudah dicapai, tetapi bagian dasarnya masih mendatar dan belum tampak pengerjaan lanjut pada sisi lateral atau bidang datar. Dibandingkan dengan mata panah dari situs terbuka lainnya berkonteks neolitik yang banyak dijumpai di Punung, maka mata panah dari Song Keplek ini dapat digolongkan sebagai mata panah setengah jadi, karena bentuk dan pengerjaan final belum dicapai.

Selain tipe temuan di atas, masih ditemukan produk alat litik lainnya yang secara kuantitas lebih sedikit jumlahnya yaitu : pisau berpunggung korteks dan "limace". Produk pertama merupakan serpih tebal berbentuk persegi atau segitiga sebagai produk awal, yang dicirikan oleh korteks di bidang dorsal atau serpih pangkasan pertama, dengan sisi distal memiliki retus pemakaian dan sering sejajar dengan bidang korteks. Di lain pihak, tipe "limace" merupakan alat yang dicirikan oleh morfologi tebal, dasar datar ( lano-convex) menyerupai lancipan ganda dan diretus intensif pada sisi kelilingnya.

\section{- Karakter Industri Tulang}

Selain industri litik, ciri budaya di Song Keplek lainnya adalah industri tulang. Sebagian besar alat tulang bertipe spatula sudah mengalami fosilisasi, sementara untuk tipe alat lainnya dibuat dari tulang binatang yang lebih segar. Secara menyeluruh, tipe yang dihasilkan adalah : spatula, lancipan, dan jarum (Prasetyo, 1996).

Spatula, dicirikan oleh tajaman yang pipih dan lebar, umumnya dibuat dari tulang panjang makro fauna. Suatu tulang dibelah memanjang dan digosok bagian dalam tulang hingga rata. Tajaman dibentuk dengan gosokan lanjut di bagian luar, hingga membentuk lereng landai ke arah distal. Lebar tajaman umumnya sama dengan lebar badan atau pangkal alat, tetapi dengan sudut-sudut melengkung yang dibentuk secara sengaja atau aus karena pemakaian. Pengerasan bagian tajaman dilakukan dengan pembakaran. 
Lancipan, umumnya dibuat dari tulang panjang dengan bagian distal yang meruncing. Bentuknya kadang simetris melalui pengerjaan di kedua sisi, atau asimetris dengan pengerjaan di salah satu sisinya. Bekas-bekas pangkasan di bagian dalam tulang ada kalanya dihaluskan lagi melalui penggosokan, tetapi terbatas untuk menghilangkan kekasarannya saja. Bagian lancipan sering mempunyai permukaan yang halus dan mengkilap melebihi bagian lainnya, dan ini merupakan bukti adanya penggosokan dan pemakaian yang intensif.

Jarum, dibedakan dari lancipan berdasarkan aspek metrik, berukuran lebih kecil dengan panjang kurang dari $5 \mathrm{~cm}$ dan garis tengah sekitar $0.5 \mathrm{~cm}$. Umumnya jarum dibuat dari tulang panjang (tibia, fibula) Aves sp., dibuat memanjang dengan salah satu ujungnya runcing melalui penggosokan salah satu sisi hingga membentuk lereng runcingan. Bagian runcing sering kali dikeraskan melalui pembakaran.

\section{- Karakter Industri Cangkang Kerang}

Berbagai alat dari cangkang kerang juga ditemukan di antara himpunan budaya Song Keplek. Hampir semua alat kerang ini dibuat dari cangkang Veneridae, ke dalam tipe alat serut, penusuk, dan sudip (Prasetyo, 1996). Serut dicirikan oleh adanya retus bersambung yang menutupi sisi atau sebagian sisi alat, yang berdasarkan morfologinya, dapat dibedakan kedalam bentuk bulan sabit, segitiga, oval, persegi, dan tidak beraturan. Di lain pihak, tipe penusuk dibentuk melalui peruncingan pada sisi tertentu, yang kemudian disempurnakan melalui penggosokan hingga menghasilkan runcingan pada sisinya.

Selain dari artefak teknomik di atas, hasil ekskavasi menunjukkan pula adanya unsur perhiasan yang berupa bandul kalung dari jenis Patelidae dan manik-manik kerang dari jenis Nautius. Cara pengerjaannya bandul kalung sangat sederhana, yaitu digosok pada bagian apexnya, kemudian dilubangi untuk memasukkan talinya. Di lain pihak, manik-manik eangkang kerang dikerjakan dengan pengambilan bagian operculumnya, kemudian dilubangi pada bagian tengahnya untuk diuntai dengan tali.

\section{- Sisa Fauna}

Eksploitasi sumber daya fauna dalam kehidupan di Song Keplek telah tampak pada temuan yang sangat padat sejak permulaan ekskavasi. Sisa-sisa fauna berupa fragmen tengkorak, tulang-tulang panjang yang masih utuh ataupun fragmentaris, dan gigigeligi, tersebar dengan kepadatan yang bervariasi di dalam gua, bercampur dengan akumulasi artefak dan ekofak lainnya. Identifikasi terhadap sisa fauna ini telah memperjelas jenis-jenis fauna yang pernah hidup di daerah ini. Kelas Mamalia paling 
dominan, meliputi Bovidae (sapi, kerbau, banteng), Suidae (babi), Elephantidae (gajah), Cervidae (rusa), Viveridae (musang), Mustelidae (lingsang), Chiroptidae (kalong), Rhinoceros (badak), Hystricidae (landak), Muridae (tikus), Sciuridae (tupai), Cercopithecidae (monyet). Jenis Macaca $s p$. (monyet) sangat dominan, umumnya berupa rahang yang masih lengkap atau sebagian gigi-geliginya.

Jenis Reptilia terdiri atas Chelonidae (penyu laut) dan Testudinidae (kura-kura darat). Sementara jenis moluska cukup menonjol, dengan Kelas Pelecypoda dari famili Vaneridae lebih dominan. Temuan lain berasal dari kelas Gastropoda darat seperti Landouria sp.. Lagochilus sp., Helecinidae, dan sebagainya. Gastropoda air tawar antara lain Thiaridae, Lymnaeidae, Pelidae, dan Certhiidae, sementara Gastropoda laut antara lain Haliotidae, Cypraeidae, dan Neritidae.

Keberadaan sisa fauna dalam konteks budaya dan hunian di Song Keplek menunjukkan keterikatan yang erat dengan manusia pendukung budayanya. Faunafauna tersebut kemungkinan diperoleh dari daerah sekitarnya melalui perburuan dan pencarian di sungai dan telaga yang saat itu pernah ada. Adanya unsur kerang laut menunjukkan upaya eksploitasi manusia hingga daerah pantai sejauh antara 15-20 kilometer untuk pemanfaatan sumberdaya laut.

\section{- Manusia Song Keplek}

Bukti-bukti pertama sisa manusia di Song Keplek dihasilkan pada tahun 1992, ketika 3 komponen tengkorak yang mewakili 3 individu ditemukan dari kotak D3 dan B6 (Widianto, 1994), yang diduga merupakan hasil penguburan sekunder, dalam lapisan abu dengan konteks serpih dan tulang binatang. Hasil pertanggalan C-14 pada level ini menunjukkan usia $4510 \pm 90$ BP (Simanjuntak, 1998), atau pada bagian akhir tingkatan pre-neolitik. Sementara penelitian tahun 1996 dan 1997 telah menghasilkan sebuah rangka relatif utuh di kotak LU2 pada kedalaman $112 \mathrm{~cm}$, dari sistem penguburan primer terlipat. Pertanggalan C-14 terhadap sampel arang yang terdapat di sekitar kubur menunjukkan angka $5.900 \pm 180 \mathrm{BP}$. Hingga penelitian tahun 1996, temuan sisa manusia di Song Keplek berjumlah 4 individu (Widianto, 1999a).

Ekskavasi lanjutan yang dilakukan pada tahun 1999 telah menghasilkan satu individu rangka yang relatif utuh pada kotak $\mathrm{H} 9$ dan 19 , yang menupakan bagian dari penguburan primer telentang, dengan kedua tangan menyilang di atas dada. Terletak pada kedalaman antara $-125 \mathrm{~cm}$ dan $-140 \mathrm{~cm}$ dari permukaan tanah, rangka ini yang selanjutnya disebut sebagai individu ke lima (Widianto, 1999b), berasosiasi dengan sebuah spatula tulang dan serpih-serpih rijang. Hingga makalah ini ditulis, masih belum dilakukan analisis $\mathrm{C}-14$ nya, sehingga pertanggalan 
absolutnya belum dapat diketahui. Meski demikian, berdasarkan keletakannya yang berada pada lapisan ke-3, ditafsirkan bahwa pertanggalan individu ini adalah antara 6.000 - 7.500 tahun BP. Dalam identifikasi sisa manusia ini, individu ke lima tersebut akan dibahas secara terpisah dari empat individu lainnya, karena adanya perbedaan karakter morfologis yang cukup nyata. Berikut ini adalah karakter morfologis dari 4 empat individu pertama.

Individu pertama, terdiri atas bagian belakang calva (parietal kanan, temporal kanan, dan bagian kanan occipital), bagian kiri temporal, fragmen rahang atas dari bagian kiri arcus alveolaris dengan beberapa gigi-geliginya (I2, C, P1, M1, M2, M3 kiri, serta M1-M3 kanan). Ukuran gigi tersebut sangat besar dengan perkembangan kuspid yang sempurna untuk P1 hingga M3. Ukuran dan morfologi bagian oklusal menunjukkan milik individu dewasa. Selebihnya, derajad sinostosa pada suturanya menunjukkan tingkatan individu dewasa muda. Eksistensi M3 menunjukkan usia individu yang telah melewati 18 tahun, sementara tingkat keausan gigi yang mencapai permukaan dentin (derajad 2 pada skala Broca) menunjukkan usia antara 35-40 tahun. Didasarkan pada ukuran processus mastoideus yang besar dan berkembangnya insersi otot pada planum nuchalis, komponen tengkorak ini mewakili individu laki-laki. Pendapat ini juga didukung oleh besarnya rahang bawah yang dimiliki (berdasarkan lebar dan dalamnya fossa mandibularis). Kedua dinding parietal ini sangat terkesan vertikal, dengan bentuk dolichocephal. Rahang atas memiliki langit-langit yang lebar dan dalam, dengan arcus alveolaris yang kekar. Kekekaran rahang tersebut dipertegas dengan ukuran gigi yang sangat besar.

Individu kedua terdiri atas fragmen temporal kiri yang meliputi processus mastoideus, meatus acusticus externus, fossa mandibularis, eminentia arcuata dan tegmen tympani. Segi fisik morfologi menunjukkan bahwa individu ini lebih kekar dibandingkan dengan individu pertama, berdasarkan lebih besarnya ukuran processus zygomaticus, lebih berkembangnya tuberculus zygomaticus anterior dan posterior, lebih intensifnya perkembangan eminentia arcuata dan tegmen tympani, lebih luas dan lebih dalamnya sulcus sinus petrosi superior, serta lebih lebar dan lebih dalamnya fossa mandibularis. Jelas mewakili individu laki-laki, usianya tidak dapat diperkirakan mengingat absennya parameter untuk penentuan usia individu.

Individu ketiga diwakili oleh sebuah calva yang terdiri atas parietal kanan dan kiri, serta bagian kanan occipital yang mencakup pula bagian planum occipitalis dan planum nuchalis. Kedua sutura yang terkonservasi --sutura sagittalis dan sutura lamboidea-- masih cukup terbuka. Dengan didasarkan pada tipisnya tulang tengkorak dengan derajad kalsifikasi cukup awal, tingkatan sinostosa sutura, dan juga perkembangan relief pada planum nuchalis, individu ini mewakili individu 
anak-anak. Berdasarkan belum tampaknya fruticulum posterior di daerah lambda, usia anak ini diperkirakan antara 7-9 tahun. Bentuk calva, meski masih anak-anak, telah menunjukkan bentuk memanjang (dolichocephal).

Individu keempat adalah sebuah temuan rangka yang sangat spektakuler, dihasilkan pada kotak LU2 tahun 1996, dengan konteks serpih-serpih dan sisa fauna. Terletak relatif di dinding selatan, rangka ini - sebagai individu keempat di Song Keplek - berada pada lapisan lempung pasiran coklat tua, dengan pertanggalan $5900 \pm 180 \mathrm{BP}$ (Simanjuntak, 1998). Lengkapnya komponen rangka menunjukkan bagian dari sistem penguburan primer, yang berdasarkan posisinya, merupakan teknik penguburan terlipat miring ke kanan. Anggota badan bagian kanan berada di atas, telapak tangan kiri berada di atas dagu kiri, lutut terangkat ke atas (Gambar 2A). Masing-masing bagian rangka masih terletak pada susunan anatomisnya. Bagian tengkorak relatif masih utuh, dengan bentuk memanjang antero-posterior (dolichocephal). Kontur sagittal pada norma lateralis terkesan mendatar, yang kemudian menurun dengan membentuk depresi pre-lambda dan melengkung ke dalam dengan membentuk tonjolan pada bagian occipital. Kedua dinding parietal terlihat cukup vertikal, dengan pelipis yang tidak membulat benar. Linea temporalis superior dan inferior tidak tampak karena tertutup sedimen. Processus mastoideus termasuk dalam ukuran kecil. Os occipitalis relatif masih utuh, meski pars basilaris dan condylus occipitalis tidak tampak. Sutura pada tengkorak tidak tampak karena tertutup sedimen, kecuali sutura parieto-temporalis bagian kiri jelas, berbentuk cembung. Prognatisme terkesan sangat kuat pada mukanya, baik untuk rahang atas maupun rahang bawah. Di bagian kanan, margo orbitalis superior pada os zygomaticus berbentuk tajam, dengan orbit mata yang berbentuk relatif bundar. Mandibula terlihat kekar, dengan ramus lebar dan processus condylaris berukuran besar. Gigi-geligi berukuran kekar, hampir lengkap, kecuali I1, I2, P2 kanan atas, dan I2 kiri bawah.

Bagian proksimal humerus kiri masih melekat pada scapula, dengan radius yang terlipat ke atas ke bagian dagu. Tulang ruas belakang masih dapat diidentifikasi secara jelas, berada di antara kedua sisi tulang rusuk, yang bagian kirinya masih menyiratkan bentuk rongga dada. Tulang belakang yang terekspos adalah bagian dari vertebrae cervicalus, thoracicae, dan lumbares, relatif lengkap. Rangkaian tulang belakang ini berlanjut hingga sacrum, dan berkait dengan kedua coxae dan kedua femur. Caput femoralis masih melekat dengan acetabulumnya. Dalam posisi yang terlipat ke atas, distal femur menyatu dengan proksimal tibia, tanpa sama sekali ditemukan kembali kedua patella. Selanjutnya, pada bagian pergelangan kaki masih bisa ditemukan calcaneus dan phalanx lainnya. Posisi rangka menunjukkan kedua telapak kaki berada di belakang tulang pinggul.

Rangka ini milik individu perempuan, atas dasar kecilnya ukuran processus 
mastoideus, bentuk orbit mata, dan relatif tajamnya margo supra-orbitalis. Status jenis kelamin itu juga digarisbawahi oleh datamya bagian arcus superciliaris maupun tidak berkembangnya relief muskuler pada planum nuchalis. Demikian pula bentuk tulang pinggul yang lebar, dengan cavitas pelvis, incisura sciatica major, dan foramen obturatum yang secara signifikan berbentuk melebar. Di lain pihak, telah enupsinya M3 dan derajad keausan gigi geraham yang telah mencapai dentin diperkirakan mewakili individu yang telah melewati usia 50 tahun.

Hingga temuan rangka pada tahun 1996 tersebut, Song Keplek telah menyumbangkan 4 individu manusia : dua laki-laki, satu perempuan, dan satu individu anakanak yang belum dapat ditentukan jenis kelaminnya. Satu di antaranya merupakan temuan rangka yang terkonservasi secara relatif bagus.

\section{- Siapakah Mereka?}

Temuan empat individu manusia penghuni Song Keplek di Gunung Sewu tersebut antara lain telah mampu menjawab pertanyaan yang muncul lebih dari setengah abad silam tentang pendukung budaya gua prasejarah di daerah ini. Ruang-ruang kosong tentang aspek manusia, setidaknya sejak 10.000 tahun terakhir, mulai terisi oleh bukti sisa rangka dari Song Keplek. Pertanggalan C-14 yang telah diperoleh bagi temuan tersebut telah mampu mengisi paro pertama Kala Holosen yang telah berlangsung, pada tingkatan teknologis yang disebut tingkatan pre-neolitik. Memang kerja keras van Rietschoten tahun 1889 dan Eugene Dubois tahun 1890 di Desa Campurdarat (Tulungagung) telah berbuah mengesankan dengan temuan manusia Wadjak 1 dan Wadjak 2, yang dikenal sebagai temuan fosil Homo sapiens yang pertama. Akan tetapi, kronologi absolut kedua fosil yang belum jelas hingga saat ini tetap merupakan persoalan klasik yang akan selalu aktual untuk dipertanyakan, sehingga membuat status keduanya menjadi tidak menentu.

Hampir pasti, sisa manusia di Song Keplek adalah pendukung budaya kehidupan gua di kawasan Gunung Sewu, karena data kontekstual antara sisa manusia dengan himpunan artefak (litik dan tulang) dan sisa fauna sangat meyakinkan. Lalu, siapakah mereka sebenarnya ? Untuk sampai pada pemahaman akan identitas mereka, kita pun akan kembali mencermati aspek fisik keempat sisa manusia itu. Tiga individu tergolong pada individu dewasa dengan karakter morfologis yang telah benar-benar berkembang, sehingga telaah dari padanya akan dapat dipakai sebagai dasar identifikasi jenis manusianya. Selebihnya, satu individu muda dari Song Keplek --berusia antara 7 sampai 9 tahun-- meski belum maksimal berkembang karakter fisiknya, masih pula dapat dimanfaatkan beberapa cirinya melalui bentuk atap tengkoraknya. 
Bentuk tengkorak menjadi salah satu sifat penentu. Individu keempat dari Song Keplek --terdifinisi dalam tulisan ini-- dapat mewakili bentuk tengkorak secara utuh, yang merupakan tengkorak berbentuk lonjong (dolichocephal). Selebihnya, individu pertama (meski hanya terkonservasi bagian infero-posteriornya), menunjukkan orientasi dinding parietal yang vertikal, sementara atap tengkorak anak-anak juga nyata-nyata memanjang secara antero-posterior. Dua karakter pokok yang dapat diketahui dari bentuk tengkorak ini adalah dolichocephal dan dinding parietal yang relatif vertikal. Ciri tengkorak seperti ini untuk kalangan Homo sapiens menunjuk pada ciri-ciri bentuk tengkorak Austromelanesid. Pada individu keempat dari Song Keplek, ciri Austromelanesid diperkuat oleh adanya depresi pre-lambda yang akhirnya memberikan bentuk menonjol pada bagian median occipitalnya. Di kalangan ras Mongoloid, bentuk tengkorak yang umum ditemukan adalah brachycephal, tanpa tonjolan di bagian occipitalnya. Hanya individu kedua yang tidak dapat diketahui aspek bentuk tengkoraknya, mengingat situasi konservasi material yang kurang baik.

Ciri Austromelanesid pada bentuk tengkorak tersebut diperkuat oleh aspek prognatisma menonjol pada mukanya. Situasi seperti ini terlihat jelas pada morfologi alat-alat mastikasi cranio-facial nya : rahang atas dan bawah, serta morfologi dan ukuran giginya. Individu keempat nyata-nyata menunjukkan ciri prognatisma : rahang atas (dan bawah) menjorok ke muka, dengan langit-langit yang lebar dan dalam. Ciri langit-langit yang sama juga ditunjukkan oleh maxilla pada individu pertama. Seluruh gigi yang terdapat pada sisa rangka dari Song Keplek merupakan gigi-geligi dalam dimensi besar, masuk secara sempurna dalam variasi ukuran gigi di kalangan Austromelanesid.

Selain pada aspek bentuk tengkorak dolichocephal, prognatisma menonjol, dan kekekaran alat-alat pengunyahnya, ciri Austromelanesid juga dapat dilihat pada kekekaran tulang tubuh secara menyeluruh. Postur tubuh ras Australomelanesoid lebih tinggi dan lebih kekar dibandingkan dengan ras Mongoloid. Pada sisa rangka dari Song Keplek, situasi seperti ini terlihat pada tulang tengkorak yang tebal, dan lebih besarnya tulang-tulang anggota badan, baik anggota badan atas (tangan) maupun anggota badan bawah (kaki). Rangka individu keempat menunjukkan kriteria tersebut. Dalam berbagai bagian, ukuran tulang panjang pada individu keempat tersebut mengesankan ukuran yang lebih kekar dari individu di kalangan ras Mongoloid.

Di luar kriteria morfologis yang telah disebutkan di atas, sebenarnya masih terdapat beberapa aspek cranio-facial yang dapat dipakai sebagai parameter identifikasi jenis ras di kalangan Homo sapiens, seperti halnya morfologis torus supra-orbitalis, lunas sagittal, ukuran akar hidung, bentuk dan ukuran muka. Sayang sekali berbagai faktor tersebut belum dapat diamati karena muka yang 
dimiliki oleh individu keempat belum dapat dilihat secara menyeluruh, karena sisa rangka belum diambil dan sebagian dari padanya masih tertutup tanah. Untuk dapat mengetahui aspek mukanya, maka diperlukan langkah lanjut berupa mengangkat dan merekonstruksinya. Meski demikian, unsur-unsur morfologis yang telah diamati di atas telah cukup representatif dan telah secara jelas membawa pada kesimpulan identifikasi sisa manusia di Song Keplek ke dalam ras Austromelanesid.

\section{- Individu ke lima}

Sebuah rangka manusia yang terkonservasi sangat bagus telah ditemukan dari kotak H9 dan I9 sebagai temuan mutakhir dalam ekskavasi di bulan Mei 1999. Kondisi rangka relatif utuh, mulai dari tengkorak hingga tumit, dan merupakan penguburan primer secara telentang lurus, dengan kedua tangan menyilang di atas dada. Orientasi rangka adalah timur-barat, kepala terletak di bagian timur. Posisi tulang tengkorak dan bagian bahu mengindikasikan pengangkatan bagian ujung kepala ke dalam, sehingga posisi dagu tampak tertunduk, berhimpitan dengan kedua clavicula yang tampak membujur searah dengan orientasi bujur rangka. Secara stratigrafis, rangka ini berada pada lapisan 3 berupa lempung coklat kemerahan, pada kedalaman $-125 \mathrm{~cm}$ (bagian kepala) dan - $140 \mathrm{~cm}$ (bagian kaki), diukur dari SDP. Pertanggalan rangka, berdasarkan posisi stratigrafi diperkirakan antara $6.000-7.500$ tahun BP. Relatif terletak di antara 2 kotak ekskavasi, rangka ini berada di bagian utara kotak, sekitar 90 $\mathrm{cm}$ dari dinding kotak. Sebuah spatula (tulang) ditemukan berasosiasi dengan rangka ini, terletak di sebelah utara tengkorak rangka. Pertanggalan pada level rangka belum dilakukan, sehingga belum dapat diketahui pertanggalan relatifnya.

Sebagai sebuah rangka sisa penguburan, temuan ini dapat dikatakan sebagai temuan yang masih lengkap. Hal ini tidak hanya ditunjukkan oleh terkonservasinya komponen anatomis yang masih baik, tetapi digarisbawahi pula oleh situasi temuan yang masih tersusun rapi pada posisi anatomisnya. Secara umum, kondisi tulang cukup segar dan cukup rapuh, terutama pada bagian tulang belakang dari vertebrae cervicalus hingga sacrum, pada sebagian besar tulang rusuknya, dan juga pada kedua coxae. Sebaliknya, kondisi yang lebih baik dapat dilihat pada bagian rahang (terutama bagian bawah), tulang-tulang kaki, hingga sampai bagian tulang telapak tangan dan telapak kaki.

Dalam sikap tertunduk, bagian atas tulang tengkorak tidak dapat lagi ditemukan kembali. Os frontalis hanya tersisa di bagian kanan, tanpa sama sekali menunjukkan adanya sutura frontalis. Posisi frontal terhadap tengkorak relatif tegak. Kedua parietal (kanan dan kiri) hampir tidak terkonservasi sama sekali, kecuali bagian posteroinferior dari perietal kanan. Sementara, bagian tulang temporal yang tersisa hanyalah squama temporalis kanan yang menunjukkan processus mastoideus utuh dalam 
ukuran relatif kecil. Processus zygomaticus telah patah, dan hanya menyisakan bagian crista pada squama temporalisnya.

Bentuk tengkorak adalah brachychepal. Hal ini sangat berbeda dengan temuan empat individu pertama dari situs ini yang menunjukkan bentuk tengkorak dolichocephal. Meski tidak dapat diamati secara leluasa karena berada di bagian bawah, bagian occipital rangka ini tampak datar, tanpa tonjolan sama sekali. Pada norma lateralis, lengkung squama occipitalis tidaklah tajam.

Tidak seperti pada sisa rangka lainnya dari Song Keplek yang menunjukkan ciri prognathisma menonjol, aspek muka terkesan jauh lebih datar dan rata. Os nasal yang relatif utuh hampir sejajar dengan prosthion pada maxilla. Jarak kedua tulang malar tidak lebih dari $130 \mathrm{~mm}$, sementara jarak antara glabella dan prosthion adalah $87 \mathrm{~mm}$. Signifikasi kedua dimensi di atas mengindikasikan ukuran muka yang sempit dan pendek. Hal ini dapat diamati karena situasi konservasi muka yang masih baik, mulai dari kedua processus frontalis, kedua tulang malar, hingga corpus maxillae.

Bentuk orbita relatif bundar, dengan margo supra-orbitalis yang relatif tajam. Arcus supercialiaris tidak menonjol, sehingga menunjukkan tulang kenin yang datar. Os nasal relatif utuh, dengan akar hidung pendek. Sementara, corpus maxillae masih terkonservasi baik, dengan processus alveolaris yang relatif utuh. Gigi-geligi yang tersisa adalah : I1, P2, M1, M2, M3 (kanan), I1, P1, P2, M1, M2, dan M3 (kiri). Di lain pihak, rahang bawah sama sekali masih utuh, dengan corpus, ramus, dan bagian symphysis yang sempurna. Di bagian kanan, tampak processus coronoideus dan processus condylaris yang masih utuh. Tidak ada satu gigi pun yang telah hilang, sehingga rahang bawah ini masih secara baik mengkonservasi arcus mandibularisnya. Sayang sekali bagian dalam rahang ini tidak dapat diamati, sehingga tidak dapat diketahui perkembangan aspek relief bagian lingualnya. Meski demikian, apabila dihadapkan pada relief insersi otot bagian luarnya dan ukuran mandibula yang ramping, tampaknya relief bagian dalamnya juga tidak berkembang. Apabila dibandingkan dengan individu lainnya dari Song Keplek, maka ukuran gigi-geligi dari individu ini terlihat lebih kecil.

Aspek infra-tengkorak tidak kalah lengkapnya dengan aspek tengkorak, yang masingmasing komponen masih berada pada posisi anatomisnya. Tangan kanan dan kiri dilipat menyilang di atas dada, dengan metacarpal kedua tangan masih lengkap, meski phalanx nya hanya tersisa sebagian, terutama pada telapak tangan kiri. Ulna kiri tidak lagi searah dengan radiusnya, tetapi bagian distalnya berada di dekat siku kanan sehingga melintang di bagian pernt. Sebagian vertebrae cervicalus masih dapat ditemukan, sementara vertebrae thoracicae, vertebrae lumbares, dan sebagian besar tulag rusuknya telah sangat rapuh. Di bagian pinggul, coxa kanan dan kiri masih 
berhubungan dengan sacrum dan caput femoralis, dan menunjukkan bentuk pelvis yang tambun dan terbuka.

Lebih ke bagian bawah, bagian distal femur menyatu dengan bagian proksimal tibia dan fibula. Kedua patella sedikit bergeser dari posisi aslinya, dan berada di sisi luar artikulasi lutut. Pada pergelangan telapak kaki masih dapat ditemukan sebagian besar tulang-tulangnya, baik kanan maupun kiri, yang terdiri atas ossa tarsi, calcaneus, astragalus, metatarsal dan phalanx jari kaki. Posisi kedua calcaneus menunjukkan bahwa pada saat individu ini dikuburkan, kedua telapak kaki terbuka, dengan kedua tumit saling bertolak belakang.

\section{- Sang Pendatang Baru}

Pemahaman kita tentang komunitas prasejarah di Song Keplek selama ini terutama didasarkan pada temuan himpunan rangka atau komponen-komponennya dari 4 individu pertama. Identifikasi rangka tersebut menunjukkan dominasi ras Austromelanesid, yang secara umumdicirikan oleh : bentuk tengkorak dolichocephal, mempunyai depresi pre-lambdatik, bagian occipital tampak menonjol, akar tulang hidup pendek, muka lebar, prognathisme menonjol, rahang (atas dan bawah) kekar dengan gigi-geligi berukuran besar, langit-langit rahang atas dalam, arcus alveolaris nyata-nyata lebih tebal dibandingkan pars basilarisnya, kadang-kadang mempunyai planum alveolaris dan torus mandibularis, rangka mengesankan kekar dengan tinggi dominan. Ciri-ciri seperti ini sangat menonjol terlihat pada rangka individu ke-4 (Widianto, 1999a), dengan teknik penguburan terlipat dalam sistem penguburan mereka. Situasi seperti ini sejalan dengan komunitas hunian gua pasca Plestosen di Jawa Timur, yairu ras Austromelanesid yang umumnya dikubur dengan teknik terlipat. Jenis ras ini mulai mengokupasi Asia Tenggara kepulauan sejak sekitar 10.000 tahun lalu (Jacob, 1967), terutama di bagian barat dan selatan. Pada saat yang sama, ras Mongoloid beremigrasi dari utara ke selatan melalui Taiwan dan Filipina, yang kemudian menghuni Indonesia bagian utara dan timur. Pada masa kemudian, sekitar 4.000 tahun silam, terjadi gelombang migrasi ras Melayu yang mengenalkan budaya neolitik (Jacob, 1967), dan akhirnya menghasilkan populasi manusia saat ini.

Kembali ke individu ke-5 dari Song Keplek. Karakter morfologis rangka individu ke lima dari kotak $\mathrm{H} 9$ dan $\mathrm{I} 9$ ini jauh berbeda dengan ciri-ciri yang terdapat pada ras Austromelanesid di atas. Bentuk tengkorak individu ini menunjuk pada bentuk brachychepal, tengkorak pendek. Dari bagian belakang tengkorak yang masih dapat diamati, individu ini sama sekali tidak mempunyai tonjolan pada bagian occipital, bahkan bagian ini terkesan datar. Muka individu ini menunjukkan muka yang pendek dan sempit, dan sama sekali tidak menunjukkan prognathisme. Kedua rahang (atas dan bawah) tidak mengesankan kekekaran melalui perkembangan reliefnya, dan 
dilengkapi dengan gigi-geligi yang lebih kecil dibandingkan dengan gigi-geligi dari individu lain di situs ini. Ukuran tulang belulangnya juga secara signifikan lebih kecil dibandingkan, misalnya, individu ke-4 yang berjenis kelamin perempuan.

Berdasarkan ciri-ciri morfologis di atas, tidak terlihat sama sekali karakter Austromelanesid pada rangka individu ke-5 dari Song Keplek ini, sehingga hampir pasti bahwa individu ini bukan bagian dari ras Austromelanesid. Sebaliknya, semua ciri yang melekat padanya mengacu pada jenis ras Mongoloid. Oleh karena itu, rangka individu ke-5 dari Song Keplek ini diidentifikasi bukan sebagai bagian dari ras Austromelanesid, tetapi ras Mongoloid.

Jenis kelamin --laki-laki atau perempuan-- dapat diidentifikasi dari aspek morfologis tengkorak dan juga tulang pinggul. Squama frontalis menunjukkan posisi relatif tegak, dengan tulang kening yang tidak menonjol, dan arcus superciliaris datar. Bentuk orbit mata adalah bundar, dengan margo supra-orbitalis pada kelopak mata yang cukup tajam. Di bagian temporal, processus mastoideus terkesan kecil apabila dibandingkan dengan ukuran tengkorak.

Tulang pinggul --meski cukup rapuh dan kurang terkonservasi secara baik-- masih memberikan beberapa ciri yang dapat diamati bagi identifikasi jenis kelamin. Secara menyeluruh, pelvis dari individu ini berbentuk tambun terbuka. Bentuk tersebut tidak hanya ditunjukkan oleh pelvis secara menyeluruh, tetapi juga terlihat secara terpisah : kedua coxa tambun, demikian pula sacrumnya. Beberapa ciri lainnya seperti cavita pelvis, incisura sciatica major, dan foramen obturatum sudah tidak terkonservasi, sehingga tidak dapat diamati.

Berdasarkan karakter morfologis tengkorak dan tulang pinggul di atas, kali ini kita berhadapan dengan individu perempuan. Usia individu tidak dapat ditentukan melalui pengamatan sutura di bagian tengkorak, karena karakter ini tidak dapat lagi ditemukan, kecuali sutura temporo-parietalis. Hanya saja berdasarkan telah erupsinya M3 pada komponen gigi-geliginya, dan adanya aus gigi di kelompok gigi molar yang telah menunjukkan keausan tingkat 3 pada skala Broca (mencapai sebagian besar dentin), maka individu ini ditafsirkan telah melewati usia 50 tahun.

Hasil analisis pada rangka ke-5 di Song Keplek dari kotak H9 dan I9 pada tahun 1999 ini menunjukkan : ras Mongoloid, perempuan dewasa, usia di atas 50 tahun.

Apabila dihadapkan pada sisa rangka lainnya di Song Keplek, maka terdapat perbedaan ras. Keempat individu pertama di gua ini secara nyata merupakan bagian dari komunitas ras Austromelanesid, yang mulai masuk dari Asia Tenggara daratan sekitar 10.000 tahun silam, dan menyebar ke bagian barat dan selatan Indonesia. Sebaliknya, pada saat yang sama ras Mongoloid juga beremigrasi dari Asia Tenggara 
daratan ke Indonesia bagian utara dan timur dengan melewati Filipina dan Sulawesi. Bagaimana sisa rangka ras Mongoloid dapat sampai ke Song Keplek dan ditemukan bersama dengan ras Austromelanesid yang lebih dominan sebarannya di daerah ini ?

Menghadapi pertanyaan ini, sebaiknya kita berpikir bahwa kedua ras yang masuk dalam takson Homo sapiens, merupakan jenis manusia yang benar-benar telah tangguh dalam menyikapi lingkungannya dalam rangka adaptasi mereka. Selebihnya, hambatan geografis sudah bukan lagi merupakan hambatan serius, dan segala kemungkinan persebaran geografis bagi Homo sapiens sangat mungkin dilakukan. Ini berarti bahwa, meski sebaran utama ras Mongoloid pada periode pasca Plestosen yang selaras dengan tradisi hunian gua-gua prasejarah umumnya mendominasi Indonesia bagian utara dan timur, tidak menutup kemungkinan bahwa telah terdapat kelompokkelompok kecil ras Mongoloid yang telah mencapai daerah Indonesia bagian selatan, dan terpisah dengan kelompok induk mereka. Bahkan pada periode ini, telah terjadi campuran ras Austromelanesoid dan Mongoloid yang terlihat pada Manusia Wadjak. Sayang sekali, hingga laporan ini ditulis, pertanggalan absolut bagi sisa rangka individu ke-5 ini belum dilakukan, sehingga usia pastinya belum dapat diketahui. Dari pertanggalan yang telah dilakukan di berbagai lapisan tanah di Song Keplek ini, diperoleh variasi angka sekitar 6.000 tahun (LU2) hingga 7.500 tahun (B6) untuk lapisan 3 sebagai lapisan pengandung rangka individu ke-5 ini. Seandainya hasil pertanggalan rangka ini mengacu pada kisaran angka tersebut di atas, maka ini berarti bahwa Song Keplek pernah dihuni secara bersamaan oleh ras Austromelanesid dan ras Mongoloid, yang sama-sama mengembangkan budaya sejenis dari batu dan tulang. Kohabitasi dua ras yang berbeda pernah terjadi di gua ini, yang dalam praktek penguburannya menunjukkan --setidaknya hingga 1999-- teknik penguburan yang berbeda : ras Austromelanesid mempraktekkan penguburan terlipat (seperti umumnya kebiasaan ras ini di berbagai gua hunian di Jawa Timur), dan ras Mongoloid mempraktekkan penguburan membujur telentang. Masih ditunggu data lebih lanjut untuk mengkaji pendapat ini.

\section{- Okupasi Intensif Manusia di Song Keplek}

Dengan berbagai kelebihan yang melekat pada Song Keplek dalam berbagai segi, hasrat manusia untuk menghuni gua ini di masa prasejarah tidak lagi terhindarkan. Data stratigrafi beserta pertanggalan dan segala temuan yang dihasilkan selama 7 tahun penelitian telah membuktikan suatu okupasi manusia yang sangat intensif, terlihat dari berbagai ragam budaya yang sangat padat. Dua ras manusia --ras Austromelanesid dan Mongoloid-- terbukti telah menghuni gua ini pada masa sekitar 4.500 hingga 8.000 tahun yang lalu, dengan meninggalkan alat-alat litik, tulang, dan cangkang kerang dalam kuantitas mengagumkan. Kemampuan mengubah segumpal batu menjadi alat telah mereka kembangan secara maksimal, hingga akhirnya 
menghasilkan tipe-tipe alat yang beragam, dari serpih biasa hingga ke bentuk-bentuk yang lebih canggih, bor misalnya. Demikian pula pemanfaatan tulang dari jenis mikro dan makro fauna telah cukup maju diterapkan di lingkungan budaya gua ini, dengan ciri utama pembuatan spatula dan lancipan tulang. Selebihnya, pembuatan perhiasan secara sederhana juga telah dikembangkan, dengan memanfaatkan cangkang kerang menjadi bandul kalung dan juga untaian manik-manik. Hampir pasti bahwa akumulasi padat sisa fauna di gua ini --seperti konsepsi teoritis umumnya-- adalah bagian dari model subsistensi mereka, yang diujudkan oleh aktivitas perburuan binatang darat (mikro dan makro fauna) dan juga pengumpulan makanan dari laut. Monyet (Macaca sp.) merupakan primadona binatang buruan pada periode 4.000 hingga 8.000 tahun lalu, sementara binatang yang lebih besar seperti Cervidae dan Bovidae, merupakan ciri utama aktivitas perburuan penghuni gua pada periode yang lebih tua, hingga paling tidak sekitar 16.000 tahun silam. Dalam intensitas yang lebih ringan, kura-kura darat cukup banyak diburu.

Aktivitas manusia itu tidaklah hanya mencapai periode teoritis hunian gua pada pasca Plestosen saja sejak 10.000 tahun silam, tetapi manusia bahkan telah menghuninya sejak minimal akhir Kala Plestosen, sekitar 16.000 tahun lalu. Hal ini dibuktikan oleh hasil ekskavasi di kotak B6 pada kedalaman sekitar $520 \mathrm{~cm}$ dari permukaan tanah, yang sangat padat ditemukan alat-alat teknologi paleolitik, seperti kapak perimbas (chopper) dan kapak penetak (chopping-tool), yang berasosiasi secara erat dengan sisa rangka rusa. Distribusi alat-alat litik pada level ini juga dilengkapi oleh eksistensi alat serpih, serut, dan batu inti, yang kelak di kemudian hari tetap diteruskan pembuatan dan pemanfaatannya oleh manusia setelahnya : Austromelanesoid dan Mongoloid, setidaknya sejak 8.000 tahun lalu.

Dalam penghunian yang teramat panjang tersebut, tidak jarang mereka ditempa oleh gangguan tektonik, justru dari fisik gua, rumah mereka sendiri. Blok-blok batu gamping yang antara lain menjadi ciri dari lapisan 4 dan hampir ditemui di seluruh areal gua, merupakan bukti runtuhnya atap gua pada periode sekitar 4.000 tahun hingga 8.000 tahun yang lalu. Aktivitas tektonik tersebut berlangsung cukup lama dalam intensitas yang berbeda, dari suatu periode nuntuhan ke periode runtuhan lainnya. Meski demikian, bencana ini bukan halangan untuk menghuni gua ini secara kontinyu, karena sisa-sisa aktivitas mereka berupa perkakas penopang hidup tetap ditemukan secara padat hingga lapisan-lapisan permukaan, yang menurut pertanggalan menunjukkan angka $1940 \mathrm{BP}$.

Terima kasih disampaikan kepada Dr Truman Simanjuntak, Kepala

Bidang Prasejarah Pusat Penelitian Arkeologi Nasional, yang telah mengijinkan penggunaan data penelitian dalam penulisan makalah ini, khususnva data terbaru dari hasil ekskavasi bulan Mei 1999. 


\section{KEPUSTAKAAN}

Handini, Retno, 1996. Laporan Penelitian Song Keplek, Punung (Kabupaten Pacitan). Jakarta : Bidang Prasejarah Pusat Penelitian Arkeologi Nasional. Belum diterbitkan.

Jacob, Teuku, 1967. Some Problems Pertaining to the Racial History of the Indonesian Region : A Study of Human Skeletal and Dental Remains from Several Prehistoric Sites in Indonesia and Malaysia. Utrecht Drukkerij Neerlandia.

Prasetyo, Bagyo, 1996. Hasil Analisis Alat Tulang dari Song Keplek, Punung. Jakarta : Bidang Prasejarah Pusat Penelitian Arkeologi Nasional. Belum diterbitkan.

Simanjuntak, Truman, 1998. Budaya Awal Holosen di Gunung Sewu, dalam Evaluasi hasil Penelitian Arkeologi 1998 di Cipayung. Jakarta : Pusat Penelitian Arkeologi Nasional. Belum diterbitkan.

Simanjuntak, Truman dan Retno Handini, 1997. Laporan Penelitian Song Keplek tahun 1996 dan 1997. Jakarta : Bidang Prasejarah Pusat Penelitian Arkeologi Nasional. Belum diterbitkan.

Widianto, Harry, 1994. Laporan Analisis Komponen Manusia dari Song Keplek, Punung (Pacitan) : Individu 1 sampai 3. Jakarta : Bidang Prasejarah Pusat Penelitian Arkeologi Nasional. Belum diterbitkan.

Widianto, Harry, 1999a. Manusia Penghuni Gunung Sewu, dalam Simanjuntak (Editor) : Gunung Sewu : Eksploitasi Pada Kala Holosen. In-press.

Widianto, Harry, 1999b. Laporan Analisis Sisa Manusia dari Song Keplek : Individu ke-5. Jakarta : Bidang Prasejarah Pusat Penelitian Arkeologi Nasional. Belum diterbitkan. 

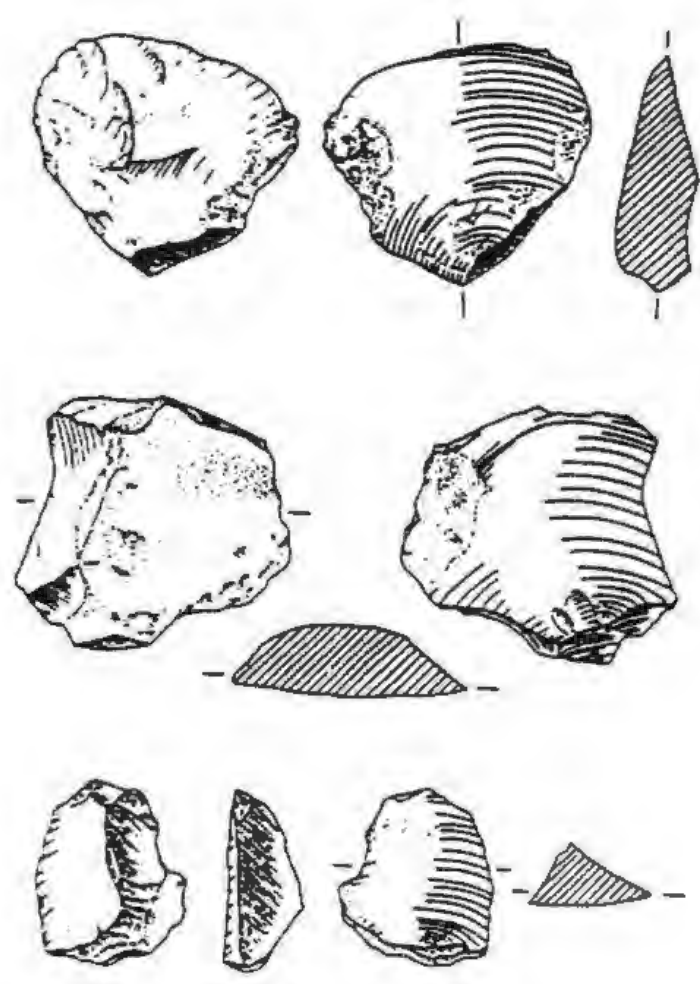

A. Serpih dengan retus

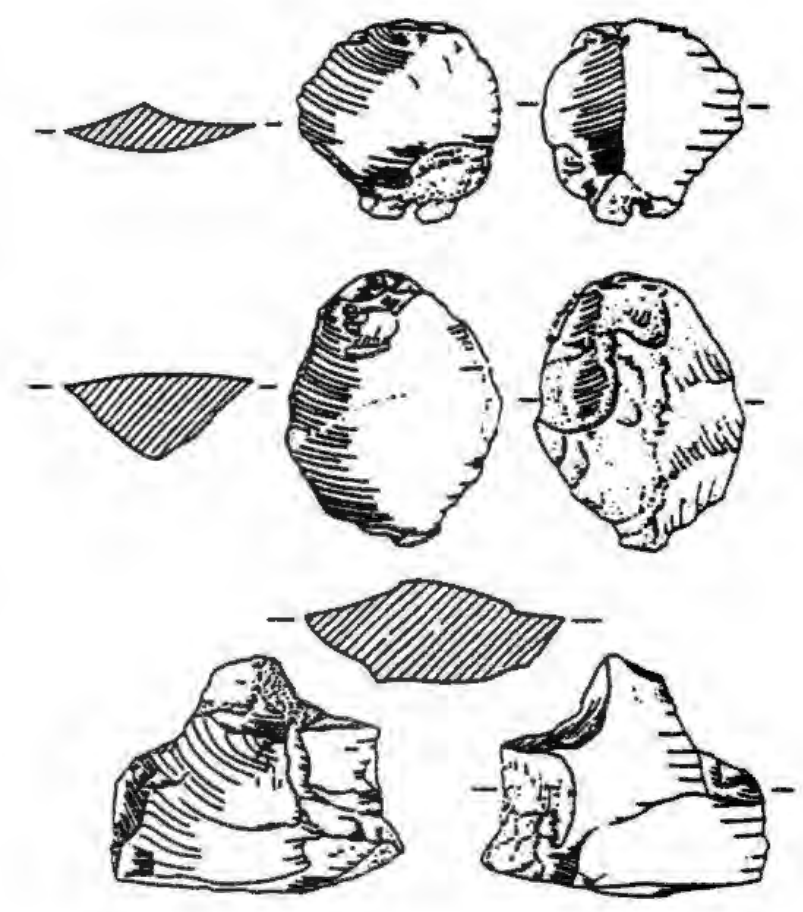

B. Serpih tanpa retus
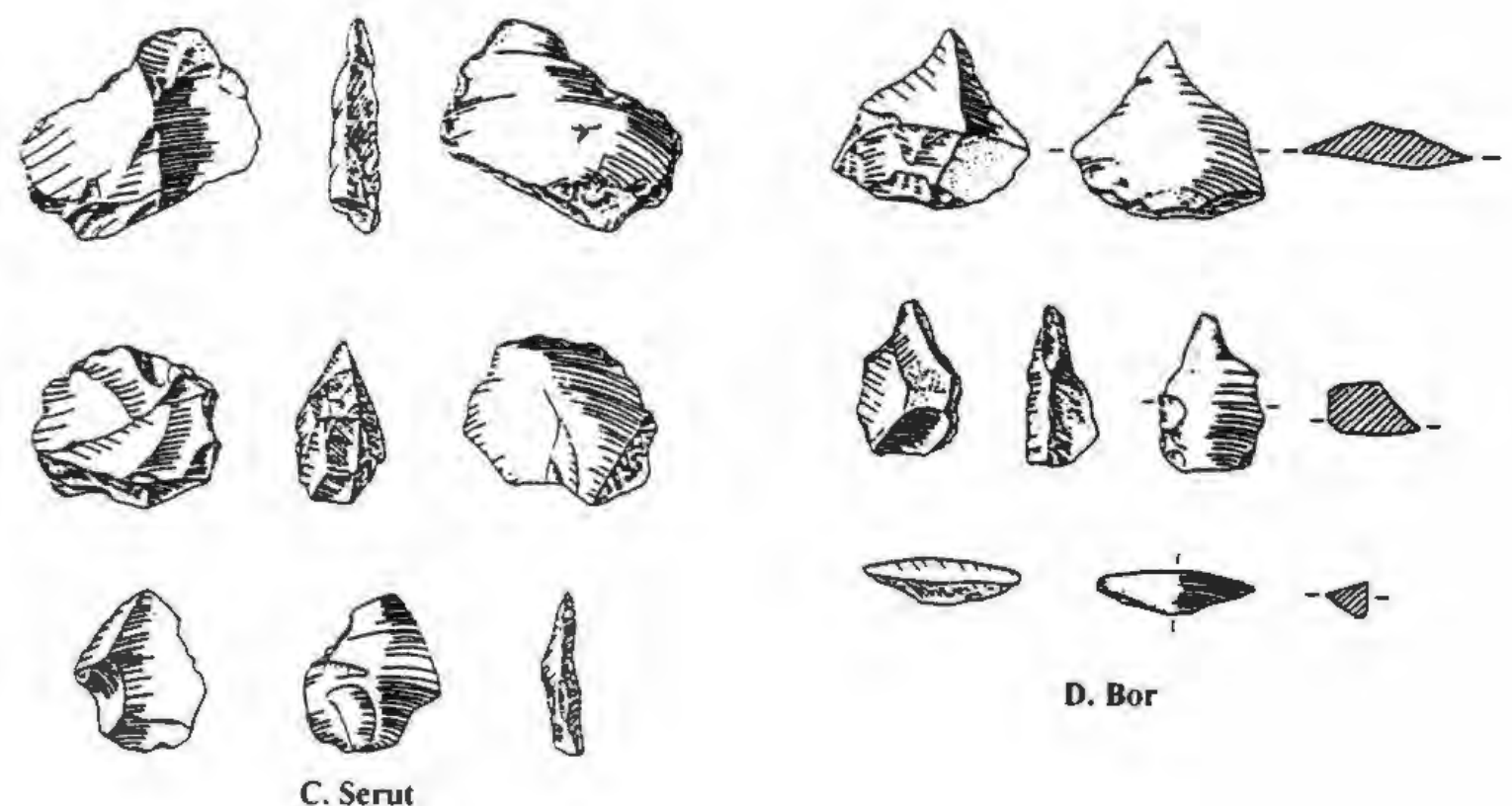

D. Bor

Gambar 1. Beberapa tipe artefak litik Song Keplek 

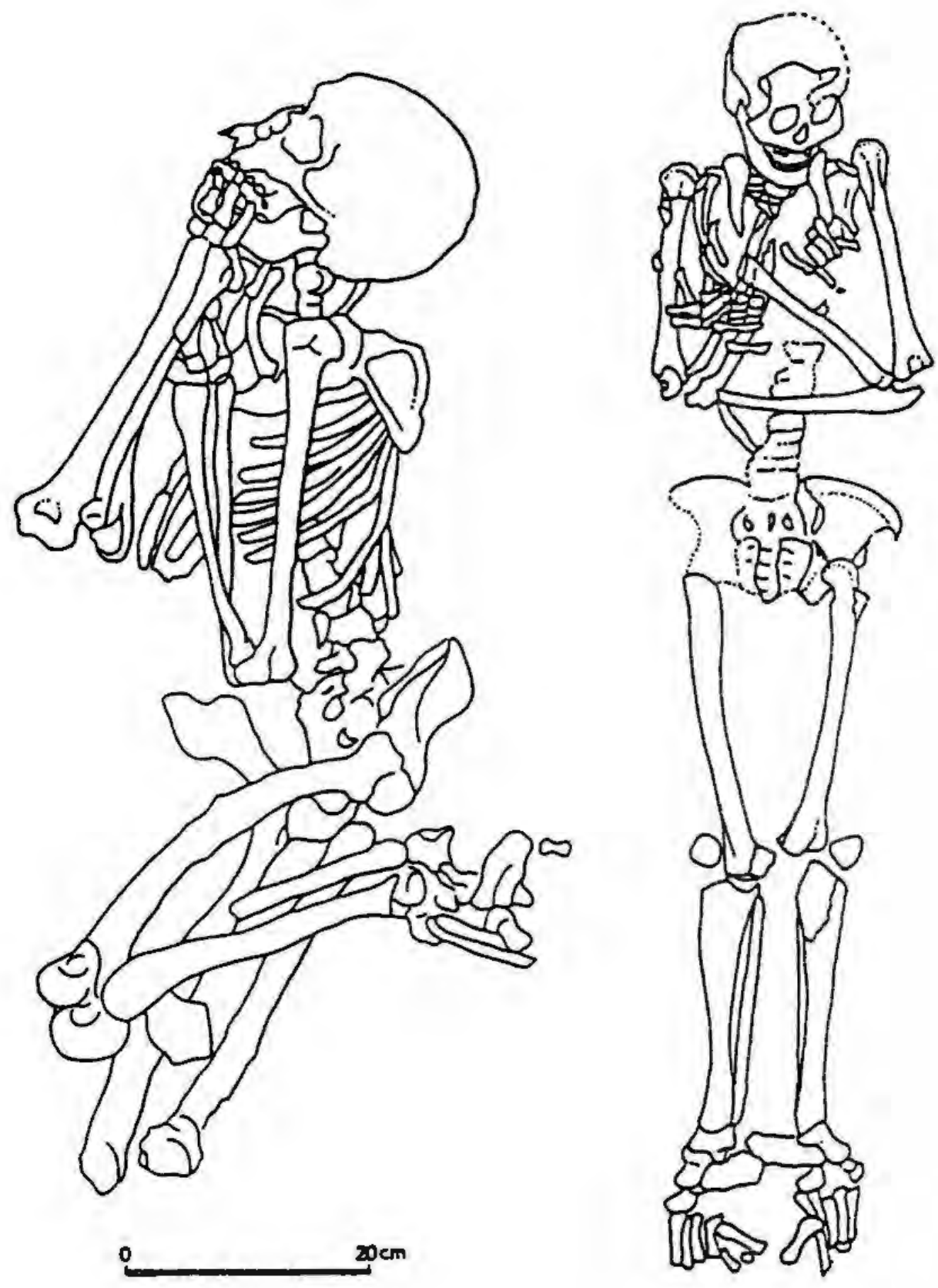

A. Individu le-t

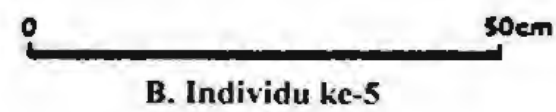

Gambar 2. Sisa Rangka Relatif Utub di Song Keplek 